\title{
Water-soluble SOA from Alkene ozonolysis: composition and droplet activation kinetics inferences from analysis of $\mathrm{CCN}$ activity
}

\author{
A. Asa-Awuku ${ }^{1, *}$, A. Nenes ${ }^{1,2}$, S. Gao ${ }^{3, * *}$, R. C. Flagan ${ }^{3,4}$, and J. H. Seinfeld ${ }^{3,4}$ \\ ${ }^{1}$ School of Chemical and Biomolecular Engineering, Georgia Institute of Technology, Atlanta, GA, USA \\ ${ }^{2}$ School of Earth and Atmospheric Sciences, Georgia Institute of Technology, Atlanta, GA, USA \\ ${ }^{3}$ Department of Environmental Science and Engineering, California Institute of Technology, Pasadena, CA, USA \\ ${ }^{4}$ Department of Chemical Engineering, California Institute of Technology, Pasadena, CA, USA \\ * now at: Department of Chemical and Environmental Engineering, University of California-Riverside, CA, USA \\ ** now at: Division of Math, Science, and Technology, Nova Southeastern University, Fort Lauderdale, FL, USA
}

Received: 7 June 2007 - Published in Atmos. Chem. Phys. Discuss.: 26 June 2007

Revised: 11 January 2010 - Accepted: 27 January 2010 - Published: 15 February 2010

\begin{abstract}
Cloud formation characteristics of the watersoluble organic fraction (WSOC) of secondary organic aerosol (SOA) formed from the ozonolysis of alkene hydrocarbons (terpinolene, 1-methlycycloheptene and cycloheptene) are studied. Based on size-resolved measurements of CCN activity (of the pure and salted WSOC samples) we estimate the average molar volume and surface tension depression associated with the WSOC using Köhler Theory Analysis (KTA). Consistent with known speciation, the results suggest that the WSOC are composed of low molecular weight species, with an effective molar mass below $200 \mathrm{~g} \mathrm{~mol}^{-1}$. The water-soluble carbon is also surface-active, depressing surface tension $10-15 \%$ from that of pure water (at CCNrelevant concentrations). The inherent hygroscopicity parameter, $\kappa$, of the WSOC ranges between 0.17 and 0.25 ; if surface tension depression and molar volume effects are considered in $\kappa$, a remarkably constant "apparent" hygroscopicity $\sim 0.3$ emerges for all samples considered. This implies that the volume fraction of soluble material in the parent aerosol is the key composition parameter required for prediction of the SOA hygroscopicity, as shifts in molar volume across samples are compensated by changes in surface tension. Finally, using "threshold droplet growth analysis", the water-soluble organics in all samples considered do not affect $\mathrm{CCN}$ activation kinetics.
\end{abstract}

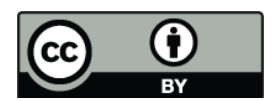

Correspondence to: A. Nenes (athanasios.nenes@gatech.edu)

\section{Introduction}

Aerosols, by acting as cloud condensation nuclei $(\mathrm{CCN})$, have a profound impact on the hydrological cycle and climate. Carbonaceous material (organic carbon, OC) can comprise up to $90 \%$ of aerosol mass (Andreae and Crutzen, 1997; Cachier et al., 1995; Yamasoe et al., 2000), 10-70\% of which may be water-soluble (WSOC). Studies have shown that WSOC can influence aerosol hygroscopicity and surface tension (Decesari et al., 2003; Saxena and Hildemann, 1996; Shulman et al., 1996) and must be characterized to quantify the impact of these aerosols on cloud droplet formation. WSOC can be present in primary organic carbon but also formed during the oxidation of volatile organic carbon (VOC) to secondary organic aerosol (SOA) (Kanakidou et al., 2005; Robinson et al., 2007; Saxena and Hildemann, 1996).

Natural VOC emissions (e.g., monoterpernes, sesquiterpenes), estimated to be $1150 \mathrm{Tg} \mathrm{yr}^{-1}$ (Guenther et al., 1995), are a major source of SOA. Alkene ozonolysis is well established as a source of SOA (e.g., Alfarra et al., 2006; Aschmann et al., 2002; Baltensperger et al., 2005; Claeys et al., 2004; Dommen et al., 2006; Forstner et al., 1997; Gao et al., 2004a; Hamilton et al., 2006; Huff-Hartz et al., 2005; Kalberer et al., 2006; Kanakidou et al., 2005; Keywood et al., 2004; Kroll et al., 2006; Limbeck et al., 2003; Shilling et al., 2007; Varutbangkul et al., 2006). Attempts to speciate SOA (Alfarra et al., 2006; Aschmann et al., 2002; Dommen et al., 2006; Gao et al., 2004a; Kalberer et al., 2006) have been met with limited success, as 80 to $90 \%$ of the aerosol mass

Published by Copernicus Publications on behalf of the European Geosciences Union. 
can remain uncharacterized (Kalberer et al., 2006; Rogge et al., 1993; Seinfeld and Pandis, 1998). The potential for forming oligomeric or polymeric structures (Baltensperger et al., 2005; Gao et al., 2004a; Gao et al., 2004b; Kalberer et al., 2004) has been suggested to explain the uncharacterized SOA fraction. Oligomers have the potential to exhibit characteristics similar to humic-like substances (HULIS) (Baltensperger et al., 2005), which strongly depress surface tension (Asa-Awuku et al., 2008; Dinar et al., 2007; Graber and Rudich, 2006; Kiss et al., 2005; Salma et al., 2006) and potentially, droplet growth kinetics. All of these can have important impacts on $\mathrm{CCN}$ activity. Adding electrolytes (particularly the bivalent $\mathrm{SO}_{4}^{2-}$ ion) to surfactant-rich solutions can enhance partitioning to the surface layer (Asa-Awuku et al., 2008; Kiss et al., 2005), and further facilitate droplet formation. Limited organic mass within the $\mathrm{CCN}$ may reduce the extent of surface tension depression (Li et al., 1998; Sorjamaa and Laaksonen, 2006; Sorjamaa et al., 2004), but depression is still required to reconcile the different hygroscopicites seen in subsaturated and supersaturated conditions for SOA aerosol (e.g., Jurányi et al., 2009; King et al., 2009; Wex et al., 2009).

Numerous studies quantifying and parameterizing the cloud droplet formation potential of SOA has increasingly appeared in the literature (e.g., but not limited to Prenni et al., 2007; Duplissy et al., 2008; Jurányi et al., 2009; King et al., 2009; Wex et al., 2009). The properties of the watersoluble fraction of the aerosol, which is by definition its dominant source of hygroscopicity, has received less attention. Engelhart et al. (2008), Asa-Awuku et al. (2009) extracted the water-soluble fraction from SOA generated from dark ozonolysis of biogenic VOC, and found that when considering surface tension depression, the water-soluble fraction had fairly constant molar mass that was consistent with known speciation, and within the limits where molecular size strongly correlates with CCN activity (Petters et al., 2009). However discrepancies have been observed for larger molecular weight compounds inferred from growth factor measurements (Brooks et al., 2004; Gysel et al., 2004; Baltensperger et al., 2005). Asa-Awuku et al. (2008) and Carrico et al. (2008) performed similar analysis to water-soluble organics extracted from biomass burning aerosol and found that most of its hygroscopicity can be attributed to low molecular weight compounds, with an inferred molar mass of $\sim 250 \mathrm{~g} \mathrm{~mol}^{-1}$. Moore et al. (2008) also studied dissolved marine organic matter isolated from the surface ocean; as expected, the matter exhibited very little hygroscopicity, but still could affect $\mathrm{CCN}$ activity by reducing surface tension by $\sim 10 \%$. Finally, Padró et al. (2010) studied water-soluble organics extracted from Mexico City aerosol, and found that the material exhibited remarkably constant hygroscopicity, regardless of location or time of day; this invariance was attributed to shifts in molar mass being compensated for changes in surface tension depression. All these studies also found that the water-soluble organic matter studied does not impede activation kinetics; in fact, Asa-Awuku et al. (2009) found evidence where the insoluble fraction was correlated with delayed activation kinetics.

In this study we report the experimental investigation of the CCN activity of the water soluble fraction of SOA generated in laboratory chamber ozonolysis of alkenes; these measurements are then used to constrain the hygroscopicity of the water-soluble organic fraction, using $\kappa$-Köhler theory (Petters and Kreidenweis, 2007). Measurements are also used to infer average thermodynamic properties (molar mass and surface tension depression), using Köhler Theory Analysis (KTA) (Asa-Awuku et al., 2008; Padró et al., 2007; Engelhart et al., 2008; Moore et al., 2008; Asa-Awuku et al., 2009). The first method, $\kappa$-Köhler theory, is used to parameterize the hygroscopicity of the aerosol for use in atmospheric models, and the latter, KTA, is employed to understand the sources of hygrosocopicity (solute versus surface tension effects) and their influence on the hygroscopicity parameter. Finally, we characterize the droplet activation kinetics by comparing activated droplet sizes from WSOC CCN against those formed from $\left(\mathrm{NH}_{4}\right)_{2} \mathrm{SO}_{4}$ calibration aerosol.

\section{Experimental methods and theoretical analysis}

\subsection{Filter extraction and chemical composition}

Secondary organic aerosol is generated from the seedless dark ozonolysis of three parent alkenes (cycloheptene, 1methylcycloheptene and terpinolene) and collected upon Teflon filters. The ozonolysis experiments were performed in the Caltech dual $28 \mathrm{~m}^{3}$ teflon chambers under dry conditions ( $>5 \%$ relative humidity), a detailed description of which can be found in Keywood et al. (2004). The ozone mixing ratio was three times that of the reactant concentration (Table 1) to ensure adequate oxidation (Gao et al., 2004a). SOA chemical speciation information measured by liquid chromatography/mass-spectrometry (LC-MS) and ion trap mass spectrometry are available for the cycloheptene and 1-methylcycloheptene precursors from Gao et al. (2004a) (Table 1). The LC-MS analysis from methanol extracts are compared to atomized water extracts presented in this study; although the exact speciation may differ between extracts, the species cited by Gao et al. (2004a) are hydrophilic and are expected to be present in the aqueous phase. No chemical speciation data are available for SOA generated from terpinolene. The presented analysis is the first study to characterize the CCN-relevant properties of WSOC from cycloheptene and 1-methylcycloheptene ozonolysis. Table 1 presents the estimated average (mole fraction weighted) molar mass and carbon to organic carbon mass ratio for the speciated organics.

Following the protocols specified for filter extraction outlined in Sullivan and Weber (2006), the WSOC in the filter samples was extracted in pure water $(18 \mathrm{M} \mathrm{Ohms})$ during 
Table 1. Characteristics of parent hydrocarbons and water-soluble fraction of SOA. Information obtained from Gao et al. (2004a).

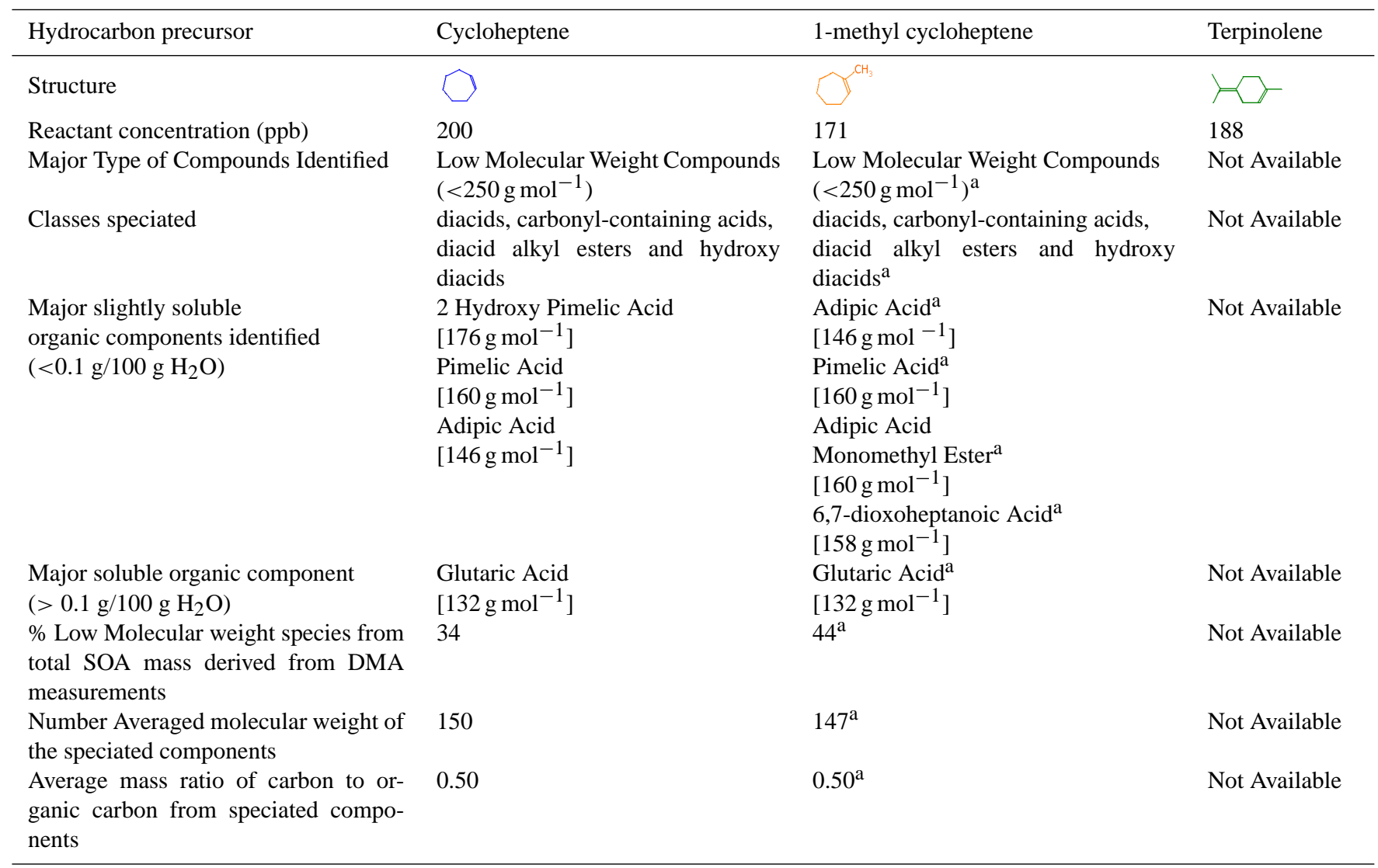

a Information obtained from 1-methylcyclohexene ozonolysis due to its structural similarity.

a $1.25 \mathrm{~h}$ sonication process with heat (water bath temperature $\sim 60^{\circ} \mathrm{C}$ ). WSOC concentration was then measured with a Total Organic Carbon (TOC) Turbo Siever analyzer (Sullivan and Weber, 2006). Anion concentrations $\left(\mathrm{SO}_{4}^{2-}, \mathrm{Cl}^{-}\right.$and $\left.\mathrm{NO}_{3}^{-}\right)$of the extracted sample were measured with the Dionex DX-500 ion chromatograph with $\mathrm{Na}_{2} \mathrm{CO}_{3} / \mathrm{NaHCO}_{3}$ eluent and Metrosep A Supp 5-100 analytical column (Metrohm, Switzerland). Table 2 provides a summary of the offline WSOC chemical composition measurements and nominal anion concentrations (less than $\left.2.55 \times 10^{-5} \mathrm{mg} \mathrm{L}^{-1}\right)$ in the extracted samples. It is possible that some carbon loss and chemical alterations of the sample may have occurred during aerosol collection, dissolution, atomization, and subsequent drying. Application of this technique however to aerosol collected from chamber SOA experiments (Engelhart et al., 2008; Asa-Awuku et al., 2009) provided properties for the WSOC that is consistent with known speciation. This suggests that water extraction may not substantially alter the properties of the WSOC.
Table 2. Summary of WSOC and ion concentrations, $\alpha$ and $\beta$ parameters of the Szyszkowski-Langmuir isotherm for all SOA considered. Measured $\mathrm{Cl}^{-}, \mathrm{SO}_{4}^{2-}$ and $\mathrm{NO}_{3}^{-}$concentrations were all below $2.55 \times 10^{-5} \mathrm{mg} \mathrm{L}^{-1}$.

\begin{tabular}{llll}
\hline $\begin{array}{l}\text { Parent } \\
\text { Hydrocarbon }\end{array}$ & $\begin{array}{l}\text { WSOC } \\
\left(\mathrm{mg} \mathrm{CL}^{-1}\right)\end{array}$ & $\begin{array}{l}\alpha^{\mathrm{a}} \\
\left(\mathrm{mN} \mathrm{m}^{-1} \mathrm{~K}^{-1}\right)\end{array}$ & $\begin{array}{l}\beta \\
\left(\mathrm{L} \mathrm{mg}^{-1}\right)\end{array}$ \\
\hline $\begin{array}{l}\text { Cycloheptene } \\
\text { 1-methyl- } \\
\text { cycloheptene }\end{array}$ & 6 & 2.59 & $1 \times 10^{-6}$ \\
Terpinolene & 10 & $4.82 \times 10^{-5}$ & $4.63 \times 10^{-19}$ \\
\hline
\end{tabular}

${ }^{a}$ Measurements are taken at room temperature between 296 and $299 \mathrm{~K}$. 


\subsection{CCN activity of SOA}

The instruments and experimental set-up used to measure WSOC CCN activity are identical to those described in AsaAwuku et al. (2008, 2009), Engelhart et al. (2008), Moore et al. (2008) and Padró et al. (2007). 3-5 ml of extracted sample is atomized in a collision type atomizer (University of Minnesota), dried with two diffusional driers and subsequently classified with a scanning mobility particle sizer (TSI SMPS 3080). A $0.71 \mathrm{~cm}$ impactor is placed on the aerosol inlet and aerosol are charged with a Kr-85 neutralizer (TSI 3077A). The sheath to flow ratio within the differential mobility analyzer (TSI DMA 3081) is kept at a constant $10 \mathrm{~L} \mathrm{~min}^{-1}$ to 1 $\mathrm{L} \mathrm{min}^{-1}$. Scanning Mobility CCN Analysis (SMCA; Nenes et al., 2010), is used to obtain fast size-resolved CCN activity (which is particularly important, given the small amount of aerosol mass available). As with "stepping" mode measurements, the classified aerosol is split to be counted by a condensation particle counter (TSI 3010) and also activated into droplets using a DMT Continuous Flow Stream-wise Thermal Gradient Chamber (Roberts and Nenes, 2005; Lance et al., 2006; Rose et al., 2008). The CCN instrument was operated at a 10:1 sheath-to-aerosol ratio, with a sample flow of $0.5 \mathrm{~L} \mathrm{~min}^{-1}$ and a top-bottom column difference, $\Delta \mathrm{T}$, between 4 and $15 \mathrm{~K}$. The total concentration $(\mathrm{CN})$ of sized particles measured by the CPC is used to determine the ratio of $\mathrm{CCN}$ to $\mathrm{CN}$. The process is repeated for different particle sizes. For each supersaturation, $s$, the cut-off diameter, $d$, (defined as the point at which the normalized distribution of $\mathrm{CCN} / \mathrm{CN}=0.5$, i.e., the particle diameter with a critical supersaturation is equal to the instrument supersaturation) provides a quantitative characterization of the SOA CCN activity (i.e., the $s-d$ relationship). The experiments are repeated a minimum of four times for each supersaturation and any influence of doubly charged particles is neglected, as discussed by Moore et al. (2008), Engelhart et al. (2008) and Asa-Awuku et al. (2009).

Calibration of the instrument supersaturation was determined by the minimum diameter of classified $\left(\mathrm{NH}_{4}\right)_{2} \mathrm{SO}_{4}$ aerosol that activated at given chamber flow rate and $\Delta \mathrm{T}$. $\left(\mathrm{NH}_{4}\right)_{2} \mathrm{SO}_{4}$ aerosol was generated by atomizing an aqueous solution and subsequently drying the droplet stream with silica-gel diffusional driers (operating at $\sim 5 \% \mathrm{RH}$ ). The resulting polydisperse dry aerosol was then charged using a Kr-85 neutralizer (TSI 3077A), and classified using a TSI 3080 SMPS with a TSI 3081 DMA operating under a sheathto-aerosol ratio of 10:1. The classified aerosol flow was split and introduced into the CPC and the CCN instrument; the concentration of total particles (or condensation nuclei, $\mathrm{CN}$ ) and $\mathrm{CCN}$ were measured, and the activation fraction $(\mathrm{CCN} / \mathrm{CN})$ was computed. This process was repeated over many classified particle sizes (between 10 and $200 \mathrm{~nm}$ ), so that an "activation curve" (i.e., $\mathrm{CCN} / \mathrm{CN}$ as a function of mobility diameter) was obtained. The activation curve exhibits a characteristic sigmoidal shape. The characteristic cut-off diameter, $d$, for the $\left(\mathrm{NH}_{4}\right)_{2} \mathrm{SO}_{4}$ aerosol for which half of the classified aerosol activates (i.e., $\mathrm{CCN} / \mathrm{CN}=0.5$ ) have a critical supersaturation, $s_{c}$, that characterizes the instrument supersaturation. Köhler theory is then used to compute $s_{c}$ from $d$, assuming that the density of $\left(\mathrm{NH}_{4}\right)_{2} \mathrm{SO}_{4}$ is equal to $1760 \mathrm{~kg} \mathrm{~m}^{-3}$, surface tension of water and a molar mass of $0.132 \mathrm{~kg} \mathrm{~mol}^{-1}$. Following the suggestions of Rose et al. (2008), the effective van't Hoff factor, $v_{s}$, was assumed to be 2.5 (additional subsequent analysis with comprehensive thermodynamic theory, gave negligible differences; Bougiatioti et al., 2009) The supersaturation uncertainty was obtained from the standard deviation in observed $d$ and never exceeded 3\% (relative uncertainty).

\subsection{Addition of inorganic salts}

The impact of adding electrolytes to the $\mathrm{CCN}$ activity of the WSOC is explored by mixing a pre-calculated amount of $\left(\mathrm{NH}_{4}\right)_{2} \mathrm{SO}_{4}$ to the dissolved SOA sample (so that the salt mass fraction in the atomized aerosol is known). The mass of organic carbon, $m_{o}$, in the extracted sample is determined by multiplying the measured WSOC carbon concentration by an organic carbon-to-carbon ratio of 2, estimated from speciation information provided in Gao et al. (2004a) and its subsequent supplemental material (Table 1). For each identified compound, the carbon to organic carbon ratio is determined from its molecular formula and weighted by its abundance in the speciated compounds. The inorganic mass to be added, $m_{i}$, to obtain the resulting inorganic mass fraction, $\alpha$, is computed as,

$m_{i}=\frac{\alpha}{(1-\alpha)} m_{o}$

where $m_{o}=2[\mathrm{WSOC}] V_{\text {sample }}$, [WSOC] is the WSOC concentration $\left(\mathrm{mg} \mathrm{CL}^{-1}\right)$, and $V_{\text {sample }}$ is the sample volume $(\mathrm{ml})$. As previously mentioned, filtered ultrapure (18 MOhm) water was used to extract the WSOC during sonication, confirmed by the negligible ions present in the filter extracts (Table 2).

\subsection{Measuring and inferring surface tension of the $\mathrm{CCN}$}

A CAM 200 pendant drop method goniometer is used to directly measure surface tension. A description of the method and procedure can be found in Asa-Awuku et al. (2008). Since the surface tension depression strongly depends on WSOC (Decesari et al., 2003; Henning et al., 2005; Kiss et al., 2005), surface tension, $\sigma$, is measured at numerous concentrations. The measurements are then fit to the Szyskowski-Langmuir isotherm (Asa-Awuku et al., 2008; Langmuir, 1917),

$\sigma=\sigma_{w}-\alpha T \ln (1+\beta c)$

where $\sigma_{w}$ is the surface tension of pure water at temperature, $T$, (obtained by infinitely diluting our sample with deionized ultra-filtered water), and $\alpha, \beta$ are empirical constants 
obtained from the fit. Unfortunately, direct measurement of $\sigma$ of WSOC solutions at concentrations relevant for $\mathrm{CCN}$ activation $\left(10^{3} \mathrm{ppm}\right.$ and above) requires significant amount of mass $\left(10^{3} \mu \mathrm{g}\right.$ and above) which was not available in the filter sample. If $\alpha, \beta$ are based on using dilute samples, extrapolation of Eq. (2) to higher concentrations is often subject to substantial uncertainty.

If the salt mass fraction exceeds $50 \%$, the majority of dissolved solute, $n_{s}$, in the aerosol is from the inorganic salt, and any surface tension depression at the droplet layer could be attributed to the presence of organics. Hence, one could then infer the droplet surface tension, $\sigma$, at the point of activation using a combination of $\mathrm{CCN}$ activation experiments and Köhler theory, as follows. For particles composed of soluble and insoluble fractions, the critical supersaturation, $s_{c}$, is (Köhler, 1936; Seinfeld and Pandis, 1998),

$s_{c}=\left(\frac{4 A^{3}}{27 B}\right)^{1 / 2}$

where $A=\left(\frac{4 M_{w} \sigma}{R T \rho_{w}}\right), B=\left(\frac{6 n_{s} M_{w}}{\pi \rho_{w}}\right), R$ is the universal gas constant, $T$ is droplet temperature, $n_{s}$ are the moles of dissolved solute. $M_{w}$ and $\rho_{w}$ are the molecular weight and density of water, respectively, and $\sigma$ is the surface tension of the droplet at the point of activation. The assumption that the inorganic salt contributes the dominant solute implies it is the only component that contributes to $B$,

$B=\frac{M_{w}}{M_{i}} \frac{\rho_{i}}{\rho_{w}} d^{3} \varepsilon_{i} v_{i}$

where $M_{i}, v_{i}$ is the average molecular weight and effective van't Hoff factor of the inorganic constituent " $i$ ", respectively. $\varepsilon_{i}$ is volume fraction of the inorganic in the aerosol, calculated from the mass fraction, $m$, and density, $\rho$, of each component as

$\varepsilon_{i}=\frac{m_{i} / \rho_{i}}{m_{i} / \rho_{i}+m_{o} / \rho_{o}}$

where " $i$ " and " $o$ " subscripts refer to inorganic and organic components, respectively. If the organic is not a strong surfactant, then the critical supersaturation $s_{c}^{*}$ for the dry diameter $d$ and volume fraction $\varepsilon_{i}$, should be given by

$s_{c}^{*}=\frac{2}{3}\left(\frac{4 M_{w} \sigma_{w}}{R T \rho_{w}}\right)^{3 / 2}\left(3 \frac{M_{w}}{M_{i}} \frac{\rho_{i}}{\rho_{w}} d^{3} \varepsilon_{i} v_{i}\right)^{-1 / 2}$

where $\sigma_{w}$ corresponds to the surface tension of pure water. However, if the organic depresses surface tension to $\sigma$ (less than $\sigma_{w}$ ), then the critical supersaturation is given by

$s_{c}=\frac{2}{3}\left(\frac{4 M_{w} \sigma}{R T \rho_{w}}\right)^{3 / 2}\left(3 \frac{M_{w}}{M_{i}} \frac{\rho_{i}}{\rho_{w}} d^{3} \varepsilon_{i} v_{i}\right)^{-1 / 2}$
If $s_{c}, \sigma_{w}, \varepsilon_{i}$ and $d$ are known from the $\mathrm{CCN}$ activity and chemical composition measurements, Eqs. (6) and (7) can be combined to give $\sigma$ :

$\sigma=\sigma_{w}\left(\frac{s_{c}}{s_{c} *}\right)^{2 / 3}$

Equation (8) represents the extension of Köhler Theory Analysis (Sect. 2.5) to infer surface tension from activation experiments. The value of $\sigma$ obtained from Eq. (8) corresponds to the concentration of dissolved carbon at the critical wet diameter of the CCN (i.e. at the point of activation), which can also be computed from Köhler theory (Padró et al., 2007; Moore et al., 2008). If the organic contribution to the Raoult term (Eq. 4) is not negligible, then it must be accounted for in Eqs. (6-8), using the procedure of Moore et al. (2008).

When $\sigma$ is inferred over a range of supersaturations (i.e. range of concentration of dissolved carbon), one can infer the relationship between surface tension and concentration of dissolved organic carbon relevant for $\mathrm{CCN}$ activation. This approach has shown to successfully reproduce surface tension measured directly with a pendant-drop goniometer (Moore et al., 2008) for primary marine organic samples.

\subsection{Köhler theory analysis (KTA) and molar volume uncertainty}

Köhler Theory Analysis (KTA; Padró et al., 2007) is used in this work to infer average molar volume (molecular weight, $M$, over density $\rho$ ) of the water-soluble organic fraction of the SOA. KTA (method $b_{1}$ ) employs measurements of dry diameter versus critical supersaturation, $s_{c}$, which are then fit to the expression, $s_{c}=\omega d^{-3 / 2}$. From the Fitted CCN activity (FCA) parameter, $\omega$, estimates of $\sigma$ and measurements of ionic and WSOC concentrations, $\frac{M_{o}}{\rho_{o}}$ is obtained as,

$$
\frac{M_{o}}{\rho_{o}}=\frac{\varepsilon_{o} v_{o}}{\frac{256}{27}\left(\frac{M_{w}}{\rho_{w}}\right)^{2}\left(\frac{1}{R T}\right)^{3} \sigma^{3} \omega^{-2}-\frac{\rho_{i}}{M_{i}} \varepsilon_{i} v_{i}}
$$

KTA has been shown to reproduce molecular weights (to within 20\%) for CCN composed of known mixtures of inorganic and organic compounds (Padró et al., 2007). KTA has also been applied to complex biomass burning WSOC with an estimated $40 \%$ uncertainty (Asa-Awuku et al., 2008). The method has also provided molar volume estimates of watersoluble extracts from biogenic SOA (Engelhart et al., 2008; Asa-Awuku et al., 2009) that is consistent with known speciation.

The measured variables employed in the KTA analysis are summarized in Table 3. In applying KTA, we assume that the effective organic van't Hoff factor, $v_{o}=1$. Molecular weights are presented assuming an average organic density of $1.4 \mathrm{~g} \mathrm{~cm}^{-3}$ (Turpin and Lim, 2001). The uncertainty in inferred molar volume is computed as $\Delta\left(\frac{M_{o}}{\rho_{o}}\right)=$ $\sqrt{\sum_{\text {for all } x}\left(\Phi_{x} \Delta x\right)^{2}}$, where $\Delta x$ is the uncertainty in of each of 
Table 3. Results from the analysis of CCN activity of all WSOC samples.

\begin{tabular}{llll}
\hline Property (units) & Cycloheptene & 1-methylcycloheptene & Terpinolene \\
\hline$\omega\left(\mathrm{m}^{1.5}\right)$ & $7.14 \times 10^{-14}$ & $5.67 \times 10^{-14}$ & $6.53 \times 10^{-14}$ \\
$\sigma\left(\mathrm{N} \mathrm{m}^{-1}\right)^{\mathrm{a}}$ & $5.99 \times 10^{-2}$ & $6.52 \times 10^{-2}$ & $6.11 \times 10^{-2}$ \\
$\left(\frac{M_{o}}{\rho_{o}}\right)\left(\mathrm{m}^{3} \mathrm{~mol}^{-1}\right)$ & $1.44 \times 10^{-4}$ & $5.69 \times 10^{-5}$ & $7.54 \times 10^{-5}$ \\
$M_{o}\left(\mathrm{~g} \mathrm{~mol}^{-1}\right)^{\mathrm{b}}$ & $207(126)^{\mathrm{c}}$ & $101(80)^{\mathrm{c}}$ & $162(106)^{\mathrm{c}}$ \\
$\kappa(\sigma)$ & $0.25 \pm 0.04$, & $0.17 \pm 0.02$, & $0.16 \pm 0.03$, \\
$\left(\kappa\left(\sigma_{\text {water }}\right)^{\mathrm{c}}\right)$ & $(0.33 \pm 0.06)^{\mathrm{c}}$ & $(0.30 \pm 0.04)^{\mathrm{c}}$ & $(0.26 \pm 0.04)^{\mathrm{c}}$ \\
\hline
\end{tabular}

a inferred from activation experiments (Table 5).

$\mathrm{b}$ Assuming the density of the solute is assumed to be $1400 \mathrm{~kg} \mathrm{~m}^{-3}$ (Turpin and Lim, 2001).

${ }^{\mathrm{c}}$ Results based on $\sigma=\sigma_{\text {water }}\left(72 \mathrm{mN} \mathrm{m}^{-1}\right)$

Table 4. Formulae for the Sensitivity of Molar Volume to the dependant parameters $\sigma, \omega$, and $v_{o}$.

\begin{tabular}{ll}
\hline Property & Sensitivity, $\Phi_{x}=\frac{\partial}{\partial x}\left(\frac{M_{o}}{\rho_{o}}\right)$ \\
\hline$\sigma$ & $\Phi_{\sigma}=\left(\frac{3 \times 256}{27}\left(\frac{M_{w}}{\rho_{w}}\right)^{2}\left(\frac{1}{R T}\right)^{3} \frac{\sigma^{2} \omega^{-2}}{\varepsilon_{o} v_{o}}\right)\left(\frac{M_{o}}{\rho_{o}}\right)^{2}$ \\
$\omega$ & $\Phi_{\omega}=\left(\frac{2 \times 256}{27}\left(\frac{M_{w}}{\rho_{w}}\right)^{2}\left(\frac{1}{R T}\right)^{3} \frac{\sigma^{3} \omega^{-3}}{\varepsilon_{o} v_{o}}\right)\left(\frac{M_{o}}{\rho_{o}}\right)^{2}$ \\
$v_{o}$ & $\Phi_{v_{o}}=\frac{256}{27}\left(\frac{M_{w}}{\rho_{w}}\right)^{2}\left(\frac{1}{R T}\right)^{3} \frac{\sigma^{3} \omega^{-2} v_{o}^{-2}}{\varepsilon_{o}}\left(\frac{M_{o}}{\rho_{o}}\right)^{2}+\left(\sum_{i \neq j} \frac{\frac{\rho_{i}}{M_{i}} \varepsilon_{i} v_{i}}{\varepsilon_{o}}\right) v_{o}^{-2}\left(\frac{M_{o}}{\rho_{o}}\right)^{2}$ \\
\hline
\end{tabular}

the measured parameters $x$, (i.e., any of $\sigma, \omega$, and $v$ ) and is the sensitivity of molar volume to $x, \Phi_{x}=\frac{\partial}{\partial x}\left(\frac{M_{o}}{\rho_{o}}\right)$, derived from Eq. (9). Table 4 provides a list of $\Phi_{x}$.

\subsection{Hygroscopicity parameter, $\kappa$}

The observed CCN activity of the WSOC can be parameterized in terms of a single hygroscopicity parameter, $\kappa$ (Petters and Kreidenweis, 2007),

$\kappa=\frac{4 A}{27 d \ln ^{2} s}$

where $A=\left(\frac{4 M_{w} \sigma_{w}}{R T \rho_{w}}\right)^{3}$, and $\sigma_{w}$ being the surface tension of water at the average instrument temperature. $\kappa$ and $\omega$ are related by $\omega=\left[\frac{4 A^{3}}{27 \kappa}\right]^{1 / 2}$. For insoluble non-wettable materials, $\kappa=0$; hygroscopic SOA exhibits $\kappa \approx 0.1$, while soluble inorganic salts exhibit much higher values (e.g., $\left(\mathrm{NH}_{4}\right)_{2} \mathrm{SO}_{4}$ has $\kappa \approx 0.6$ ). If hygroscopic SOA are assumed to be composed of a soluble fraction with volume fraction $\varepsilon_{o}$, and the surface tension at their point of activation is equal to $\sigma_{w}$, one can show,

$\kappa=\left(\frac{M_{w}}{\rho_{w}}\right)\left(\frac{\rho_{o}}{M_{o}}\right) \frac{\varepsilon_{o}}{v_{o}}$ where $\left(\frac{M_{o}}{\rho_{o}}\right)$ is the average molar volume of the soluble organic fraction and $v_{o}$ is the effective van't Hoff factor of the soluble organic. If organics depress surface tension, to a value $\sigma$ at the point of activation, application of Eq. (10) overestimates $\kappa$ by a factor of $\left(1-\frac{\sigma_{w}-\sigma}{\sigma_{w}}\right)^{-3}$.

\subsection{Droplet activation kinetics}

When exposed to the same $s$ profile (that exceeds their $s_{c}$ ) two CCN will activate and grow to cloud droplets of similar wet diameter, $D_{p}$, provided that their critical supersaturation and mass transfer coefficient of water vapor to the growing droplets is the same. The $\mathrm{CCN}$ instrument measures droplet sizes by an optical particle counter and therefore can be used to explore the impact of organics on the droplet growth kinetics. By comparing the droplet sizes of activated SOA particles against $\left(\mathrm{NH}_{4}\right)_{2} \mathrm{SO}_{4}$ particles at identical $s_{c}$ (and for identical conditions of instrument operation), we directly assess the impact of organics on $\mathrm{CCN}$ growth kinetics. In this study, we select the wet diameter, $D_{p}$, that corresponds to particles with $s_{c}$ equal to the instrument supersaturation, $s$, (i.e., $\mathrm{CCN}$ with a dry diameter equal to the cut-off diameter, $d$ ). This method, termed "Threshold droplet Growth Analysis" (TDGA), has been successfully applied in numerous studies (Asa-Awuku et al., 2008, 2009; Engelhart et al., 2008; Moore et al., 2008; Bougiatioti et al., 2009; Lance et 
Table 5. $\sigma$ values inferred at the point of activation/

\begin{tabular}{lll}
\hline Sample & $\sigma\left(\mathrm{mN} \mathrm{m}^{-1}\right)$ & $\pm \Delta \sigma\left(\mathrm{mN} \mathrm{m}^{-1}\right)$ \\
\hline Cycloheptene SOA with 90\% $\left(\mathrm{NH}_{4}\right)_{2} \mathrm{SO}_{4}$ & 73.6 & 4.6 \\
Cycloheptene SOA with 33\% $\left(\mathrm{NH}_{4}\right)_{2} \mathrm{SO}_{4}$ & 59.9 & 1.9 \\
1-methylcycloheptene SOA with 33\% $\left(\mathrm{NH}_{4}\right)_{2} \mathrm{SO}_{4}$ & 65.2 & 2.5 \\
Terpinolene SOA with 98\% $\left(\mathrm{NH}_{4}\right)_{2} \mathrm{SO}_{4}$ & 74.4 & 4.9 \\
Terpinolene SOA with 90\% $\left(\mathrm{NH}_{4}\right)_{2} \mathrm{SO}_{4}$ & 70.5 & 4.0 \\
Terpinolene SOA with 33\% $\left(\mathrm{NH}_{4}\right)_{2} \mathrm{SO}_{4}$ & 61.1 & 7.9 \\
\hline
\end{tabular}

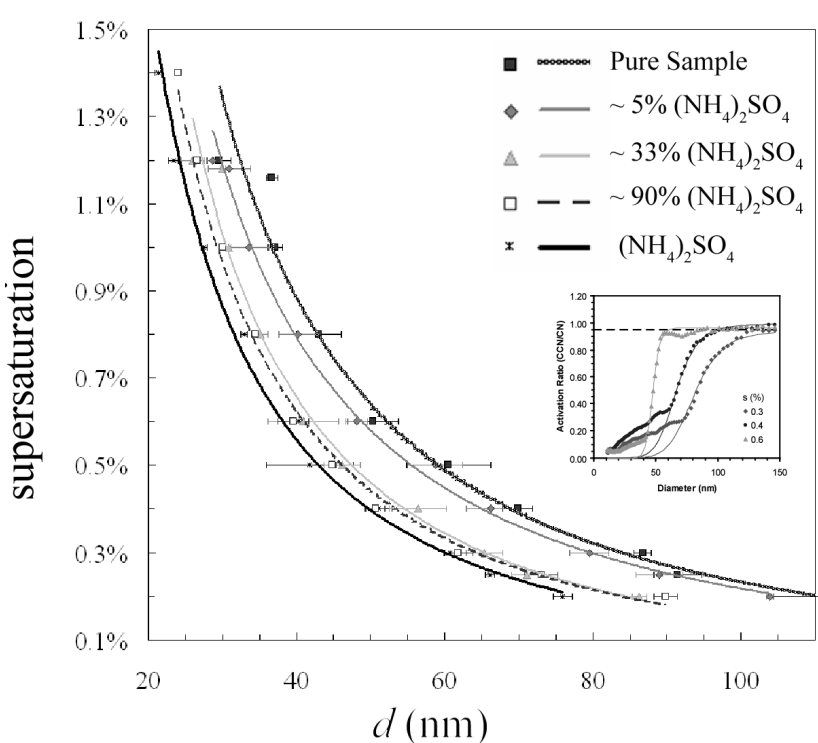

Fig. 1. CCN activity of WSOC generated from ozonolysis of cycloheptene. Results are shown for pure WSOC and mixtures of $\left(\mathrm{NH}_{4}\right)_{2} \mathrm{SO}_{4}$. The cut-off diameter, $d$, is the point at which $\mathrm{CCN} / \mathrm{CN}=0.5$ ) is plotted versus supersaturation. Lines are fit of experimental data points. Inset graph presents examples of activation curves (i.e., $\mathrm{CCN} / \mathrm{CN}$ vs. dry mobility diameter) with corresponding sigmoidal fits for pure sample aerosol.

al., 2009; Sorooshian et al., 2008; Murphy et al., 2009; Padró et al., 2010) to assess the impact of composition on activation kinetics.

\section{Results and discussion}

\subsection{CCN activity}

The cut-off diameter, $d$, as a function of supersaturation and $\left(\mathrm{NH}_{4}\right)_{2} \mathrm{SO}_{4}$ mass fraction are shown for all SOA samples in Figs. 1-3. As the mass fraction of $\left(\mathrm{NH}_{4}\right)_{2} \mathrm{SO}_{4}$ increases, the aerosol smoothly transitions to pure $\left(\mathrm{NH}_{4}\right)_{2} \mathrm{SO}_{4}$ behavior. This suggests that the SOA are soluble and hygroscopic (low molecular weight) compounds that are not strong surfactants.

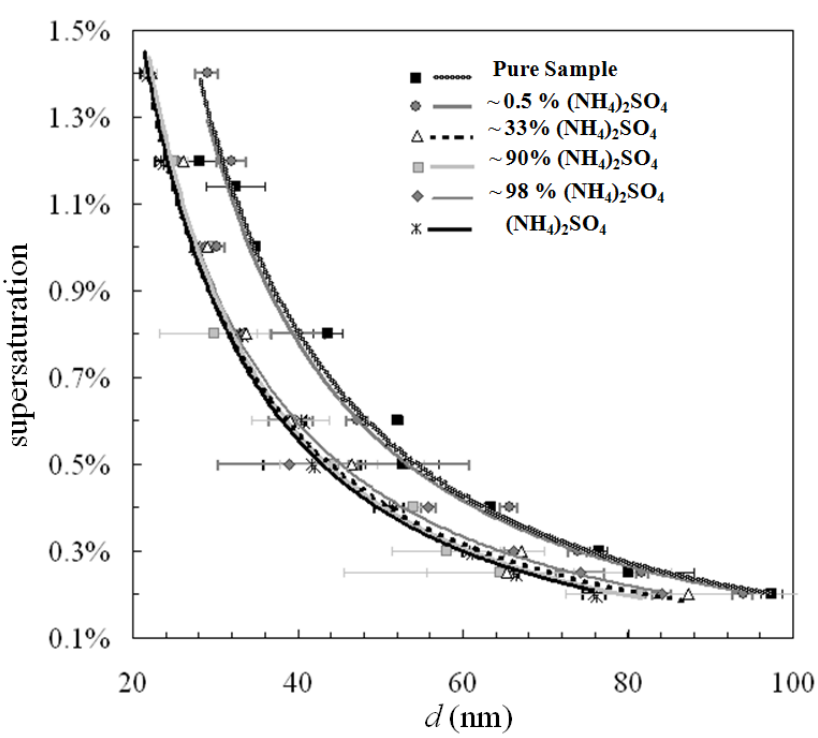

Fig. 2. CCN activity of WSOC generated from ozonolysis of terpinolene. Results are shown for pure WSOC and mixtures of $\left(\mathrm{NH}_{4}\right)_{2} \mathrm{SO}_{4}$. The cut-off diameter, $d$, is the point at which $\mathrm{CCN} / \mathrm{CN}=0.5$ ) is plotted versus supersaturation. Lines are fit of experimental data points.

For all three parent hydrocarbons, the original SOA samples activate at diameters larger than that of $\left(\mathrm{NH}_{4}\right)_{2} \mathrm{SO}_{4}$; this is expected as organics are generally less hygroscopic than soluble electrolytes. The activation curves are well represented with a power law consistent with a $d^{-3 / 2}$ dependence; this implies that the water-soluble SOA does not exhibit limited solubility over the range of critical supersaturations considered (Padró et al., 2007).

\subsection{Surface tension}

Figure 4 shows the direct measurements of surface tension for all SOA samples and the Szyskowski-Langmuir fits to the data ( $\alpha$ and $\beta$ parameters of the fits are given in Table 2). None of the samples demonstrate significant surface tension depression at measured concentrations, even when extrapolated to concentrations relevant for $\mathrm{CCN}$ activation 


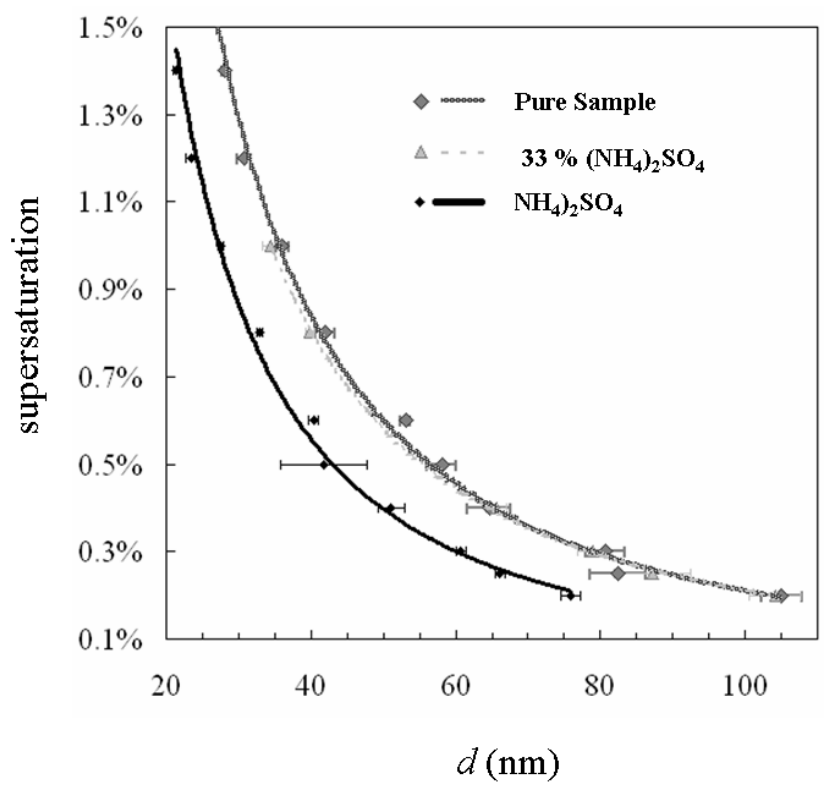

Fig. 3. CCN activity of WSOC generated from ozonolysis of 1methylcycloheptene. Results are shown for pure WSOC and mixtures of $\left(\mathrm{NH}_{4}\right)_{2} \mathrm{SO}_{4}$. The cut-off diameter, $d$, is the point at which $\mathrm{CCN} / \mathrm{CN}=0.5$ ) is plotted versus supersaturation. Lines are fit of experimental data points.

(100 $\mathrm{mg} \mathrm{C} \mathrm{L}^{-1}$ and above) (Fig. 4). If surfactants do exist in the SOA, it is likely they are not concentrated enough in the extracted samples to have a notable impact on surface tension; even for strong surfactants extracted from a biomass burning sample (Asa-Awuku et al., 2008), the depression for concentrations up to $100 \mathrm{mg} \mathrm{CL}^{-1}$ is within the measurement uncertainty (Fig. 4). Thus, direct surface tension measurements for dilute samples would not conclusively reveal the presence of surfactants. Acquiring sufficient sample for $\sigma$ measurement is challenging, so we infer surface tension using the method described in Sect. 2.4. For large mass fractions of salt ( $>90 \%$ ), the inferred surface tension approaches that of water used to extract the WSOC from the SOA filter samples $\left(\sim 72 \mathrm{mN} \mathrm{m}^{-1}\right)$ (Table 5). However, for the $33 \%$ mixture of sulfate with cycloheptene and terpinolene, the inferred $\sigma$ is $\sim 60 \mathrm{mN} \mathrm{m}^{-1}$ (Table 5), $\sim 15 \%$ depression from pure water, suggesting that surface active components indeed exist in the WSOC. The extent of surface tension depression suggests that the surfactants are appreciably strong, which is expected given the amphiphilic nature of the oxidation products. Furthermore, if micelles are formed, the ability of surface active organics to depress $\sigma$ is limited and consistent with inferred values (Tabazadeh, 2005).

\subsection{Molar volume estimates and uncertainty}

Using the inferred values of surface tension (Table 5) and assuming an aerosol density of $1.4 \mathrm{~g} \mathrm{~mol}^{-1}$ (Turpin and

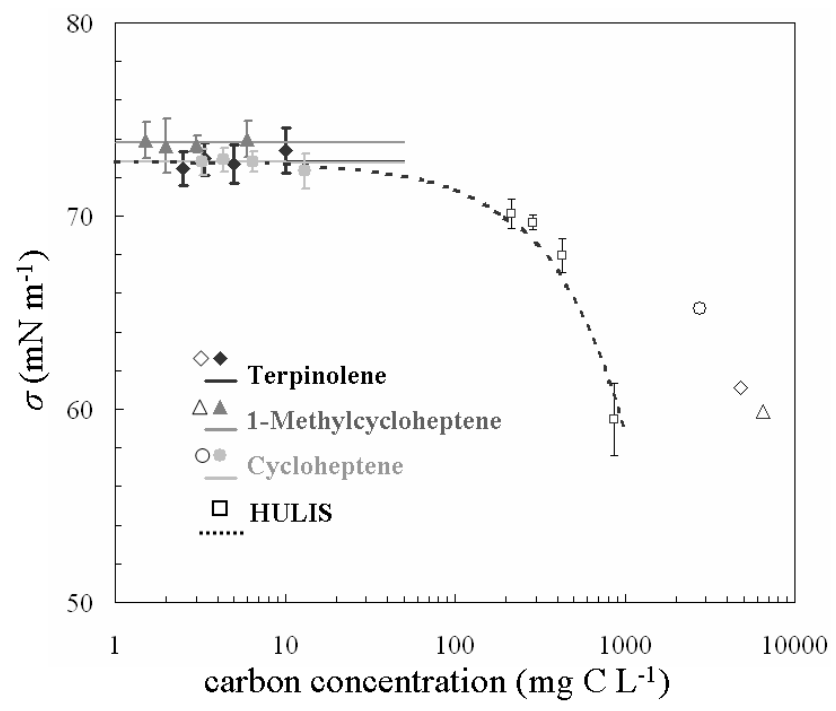

Fig. 4. Direct $\sigma$ measurements of SOA as a function of watersoluble carbon concentration (closed symbols) and inferred values from (Table 5) (open SOA symbols) as a function of water soluble carbon concentration at activation. Curves represent SzyskowskiLangmuir isotherm fits of experimental data. HULIS data from Asa-Awuku et al. (2008) is provided for comparison.

Lim, 2001), KTA gives average organic molecular weights of $162 \pm 28,101 \pm 20,207 \pm 54 \mathrm{~g} \mathrm{~mol}^{-1}$ for terpinolene, 1methyl cycloheptene, and cycloheptene SOA, respectively (Tables 3 and 6). This agrees (to within uncertainty) with the Gao et al. (2004a) speciation (Table 1), which includes low molecular weight diacids, carbonyl-containing acids, diacid alkeylsters, and hydroxyl diacids (e.g., pimelic acid, $160 \mathrm{~g} \mathrm{~mol}^{-1}$; adipic acid, $146 \mathrm{~g} \mathrm{~mol}^{-1}$; glutaric acid, $132 \mathrm{~g} \mathrm{~mol}^{-1}$; succinic acid, $118 \mathrm{~g} \mathrm{~mol}^{-1}$; pimelic acid monomethyl ester, $174 \mathrm{~g} \mathrm{~mol}^{-1}$; adipic acid monomethyl ester, $160 \mathrm{~g} \mathrm{~mol}^{-1}$; 2-hydroxypimelic acid, $176 \mathrm{~g} \mathrm{~mol}^{-1}$; 2hydroxy glutaric acid, $148 \mathrm{~g} \mathrm{~mol}^{-1}$; 6-oxohexanoic acid, 130 $\mathrm{g} \mathrm{mol}^{-1}$ and 6-oxo-7-hydroxyheptanoic acid, $158 \mathrm{~g} \mathrm{~mol}^{-1}$ ). The modest depression of inferred $\sigma$ from the value of pure water $(\sim 10 \%)$, and the value of inferred molar volume being in the range where hygroscopicity correlates with molar size (Petters et al., 2009) implies that the KTA-based estimates are representative for the WSOC. Indeed, if water surface tension was used in KTA to infer the molecular weight of the organics, large deviations arise from the Gao et al. (2004a) speciation (Tables 1 and 3).

The molar volumes of water-soluble alkene SOA inferred here $\left(5.69 \times 10^{-5}-1.44 \times 10^{-4} \mathrm{~m}^{3} \mathrm{~mol}^{-1}\right)$ are within the range inferred for WSOC from $\alpha$-pinene $\left(8.18 \times 10^{-5}\right.$ $\left.\mathrm{m}^{3} \mathrm{~mol}^{-1}\right)$, monoterpene $\left(8.36 \times 10^{-5} \mathrm{~m}^{3} \mathrm{~mol}^{-1}\right)$ and $\beta$ caryophyllene SOA $\left(1.02 \times 10^{-4} \mathrm{~m}^{3} \mathrm{~mol}^{-1}\right)$ dark ozonolysis (Engelhart et al., 2008; Asa-Awuku et al., 2009). The WSOC alkene SOA is also consistent with HULIS samples $\left(1.08 \times 10^{-4}-2.06 \times 10^{-4} \mathrm{~m}^{3} \mathrm{~mol}^{-1}\right.$; Wex et al., 2007). 
Table 6. Molar Volume Sensitivity Analysis for SOA.

\begin{tabular}{|c|c|c|c|c|}
\hline $\begin{array}{l}\text { SOA Precursor } \\
\text { Hydrocarbon }\end{array}$ & $\begin{array}{l}\text { Property } x \\
\text { (units) }\end{array}$ & $\Delta x$ & $\begin{array}{l}\Phi_{\mathrm{X}} \\
\left(\mathrm{m}^{3} \mathrm{~mol}^{-1} \mathrm{x}^{-1}\right)\end{array}$ & $\begin{array}{l}\text { Molar volume } \\
\text { uncertainty }(\%)\end{array}$ \\
\hline \multicolumn{5}{|l|}{ Terpinolene } \\
\hline & $\sigma$ & $1.41 \times 10^{-3}$ & $3.73 \times 10^{-3}$ & 7.0 \\
\hline & $\omega$ & $2.21 \times 10^{-15}$ & $2.69 \times 10^{9}$ & 7.9 \\
\hline & $v_{\text {organic }}$ & $0.20^{\mathrm{a}}$ & $8.78 \times 10^{-5}$ & 23.3 \\
\hline & \multicolumn{2}{|c|}{ Total Uncertainty } & & 26.2 \\
\hline \multicolumn{5}{|c|}{ 1-methylcycloheptene } \\
\hline & $\sigma$ & $1.40 \times 10^{-3}$ & $2.76 \times 10^{-3}$ & 6.8 \\
\hline & $\omega$ & $1.90 \times 10^{-15}$ & $2.26 \times 10^{9}$ & 7.5 \\
\hline & $v_{\text {organic }}$ & $0.20^{\mathrm{a}}$ & $6.41 \times 10^{-5}$ & 22.5 \\
\hline & \multicolumn{2}{|c|}{ Total Uncertainty } & & 25.1 \\
\hline \multicolumn{5}{|l|}{ Cycloheptene } \\
\hline & $\sigma$ & $1.21 \times 10^{-3}$ & $8.34 \times 10^{-3}$ & 7.0 \\
\hline & $\omega$ & $1.58 \times 10^{-15}$ & $4.71 \times 10^{9}$ & 5.2 \\
\hline & $v_{\text {organic }}$ & $0.20^{\mathrm{a}}$ & $1.68 \times 10^{-4}$ & 23.3 \\
\hline & \multicolumn{2}{|c|}{ Total Uncertainty } & & 26.9 \\
\hline
\end{tabular}

${ }^{\text {a }}$ Error based on observations of $20 \%$ dissociation of organic HULIS in titration experiments Dinar et al. (2006).

Assuming an organic density of $1.5 \mathrm{~g} \mathrm{~cm}^{-3}$, these molar volumes correspond to a molar mass range of about 180$250 \mathrm{~g} \mathrm{~mol}^{-1}$, which is similar to the average molar mass from the alkene SOA.

The uncertainty in inferred molar volume is affected by the uncertainty in all parameters used for KTA. First, the assumption that $v_{o}=1$, does not account for the partial dissociation of the organic species, and tends to underestimate molar volume. The potential dissociation of organics (up to $20 \%$ as measured in HULIS titration experiments; Dinar et al., 2006), contributes roughly $23 \%$ uncertainty to the molar volume estimates and is the greatest estimated source of uncertainty in molar volume (Table 6). As in previous KTA studies (e.g., Asa-Awuku et al., 2008, 2009; Padró et al., 2007; Engelhart et al., 2008, Moore et al., 2008, Padró et al., 2010), the contributions of $\sigma$ and $\omega$ variability to the inferred molar volume uncertainty are around $10 \%$ each. If one wants to estimate molar mass, uncertainty also arises from the value of density; varying from $1.4 \mathrm{~g} \mathrm{~cm}^{-3}$ to $1.6 \mathrm{~g} \mathrm{~cm}^{-3}$ (Turpin and Lim, 2001) increases molar masses by $14 \%$, which is important but still smaller than the uncertainty from $v_{o}$. The total estimated uncertainty in molar volume is approximately $25 \%$ for all SOA samples (Table 6).

\subsection{Hygroscopicity parameter, $\kappa$}

Table 3 reports $\kappa$ values for water-soluble alkene SOA. If Eq. (10) is applied assuming a surface tension of water, $\kappa$ $\sim 0.30$ for all samples. If the inferred $\sigma$ is used, $\kappa \sim 0.16-$ 0.25 . The sensitivity of $\kappa$ to the value of surface tension can provide an uncertainty for the real value of the parameter; which on average is $37 \%$ for the SOA considered here
(Table 3). Such levels of uncertainty are consistent with the studies of Engelhart et al. (2009), Padró et al. (2010), and Jurányi et al. (2009).

The $\kappa$ for the water-soluble fraction (regardless of surface tension assumption) is consistently higher than the "typical" $\kappa \sim 0.1$ found for most hygroscopic SOA (Petters and Kreidenweis, 2007). This is because the samples analyzed here reflect the water-soluble fraction of the parent SOA, and is the prime source of its hygroscopicity. The parent SOA, being a mixture of "insoluble" (non-hygroscopic) and "soluble" components inevitably has a lower $\kappa$, because the volume fraction of the WSOC, $\varepsilon_{o}$, is less than unity (Eq. 11).

A striking feature of $\kappa$ (assuming surface tension of water) is its invariance $(\kappa \sim 0.30)$ with respect to parent hydrocarbon and speciation. Even more striking is its agreement with the hygroscopicity of WSOC from monoterpene SOA (Engelhart et al., 2008), sesquiterpene SOA (Asa-Awuku et al., 2009) and Mexico City aerosol (Padró et al., 2010). Given the variable composition of the WSOC in all of these samples and the nature of the compounds involved (i.e., low molecular weight compounds, with varying surfactant capability), a constant $\kappa$ implies that shifts in molar volume between samples are accompanied by compensating shifts in surface tension depression.

\subsection{Droplet activation kinetics}

Figure 5 presents the droplet size measurements at the instrument OPC for all supersaturations and samples considered. For all points, the flow rate within the instrument was maintained constant at $0.5 \mathrm{~L} \mathrm{~min}^{-1}$ and the sheath to aerosol ratio is 10:1; this ensures that all the particles were exposed 


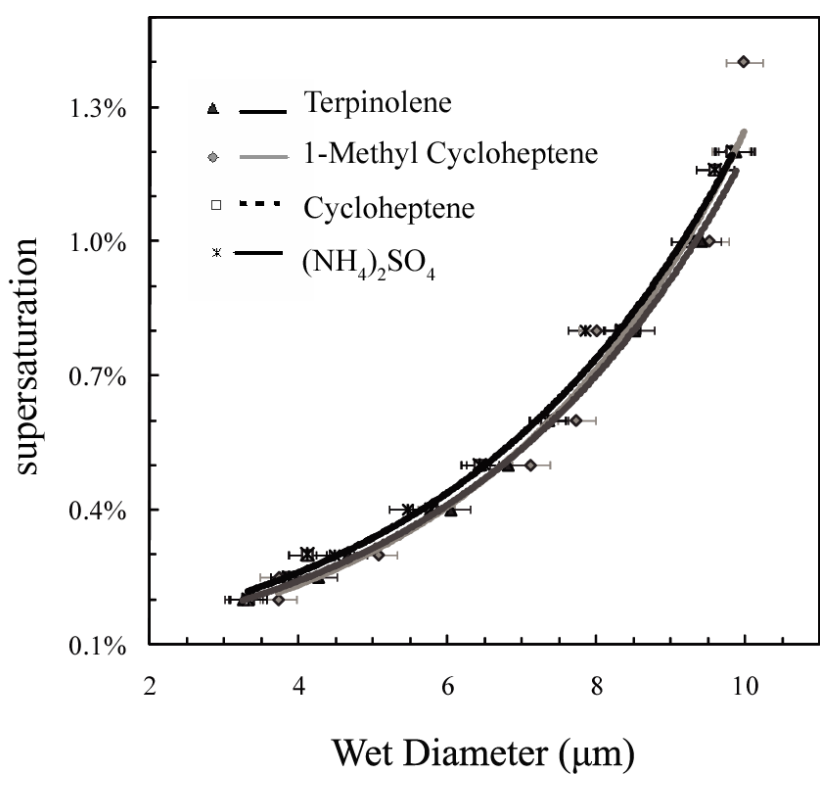

Fig. 5. Droplet growth measurements for WSOC SOA and $\left(\mathrm{NH}_{4}\right)_{2} \mathrm{SO}_{4} \mathrm{CCN}$ with critical supersaturation equal to the instrument supersaturation.

to similar supersaturation profiles. From Fig. 5 we conclude that the droplet growth kinetic curves for all SOA samples are virtually indistinguishable for all $s$ values examined; compared to $\left(\mathrm{NH}_{4}\right)_{2} \mathrm{SO}_{4}$, SOA particles grow to very similar sizes. The droplet growth of water soluble compounds from alkene SOA is similar to water soluble organics presented in Engelhart et al. (2008) and Asa-Awuku et al. (2009). Almost all of the growth kinetics experiments lie within the measurement uncertainty, so we conclude that the growth kinetics (and corresponding water vapor mass uptake coefficient) are uniform and equal to that of $\left(\mathrm{NH}_{4}\right)_{2} \mathrm{SO}_{4}$.

\section{Summary and implications}

In this study, we explore the size-resolved $\mathrm{CCN}$ activity and droplet activation kinetic characteristics of SOA generated from the ozonolysis of biogenic precursors. The data is then parameterized using $\kappa$-Köhler theory. The data is also processed with Köhler theory analysis (KTA) to infer surface tension and the average molar volume of the soluble organics extracted from the filter samples. The results of the analysis are compared against known speciation (whenever known) to evaluate the method. Finally, we compare the activated droplet sizes against a reference from ammonium sulfate calibration aerosol (using TDGA) to evaluate the impact of the dissolved organics on activation kinetics.

A number of important findings emerge from this study. First, using TDGA we find that the water-soluble organics do not affect droplet growth kinetics, as $\mathrm{CCN}$ from all the SOA samples grow to similar droplet sizes as $\left(\mathrm{NH}_{4}\right)_{2} \mathrm{SO}_{4}$ aerosol.
This finding is consistent with the studies of Engelhart et al. (2008), Asa-Awuku et al. (2009), Moore et al. (2008) and Padró et al. (2010). Second, KTA results are consistent with available composition data when using inferred surface tension values; assuming surface tension of water yields too low molecular weights. Given this and that inferences are in the range where hygroscopicity is strongly correlated with molar volume (Petters et al., 2009) suggests that appropriate application of KTA (when applied to the water-soluble fraction of the aerosol) is a powerful tool for understanding the sources of hygroscopicity (i.e., surface tension and solute contributions) of organic aerosol. Furthermore, the apparent $\kappa$ values are remarkably constant, and in agreement with values obtained in previous studies for water-soluble carbon extracted from ozonolysis SOA (e.g., Engelhart et al., 2008; Asa-Awuku et al., 2009) and Mexico City aerosol (Padró et al., 2010). When KTA is used to deconvolute the source of this hygroscopicity in terms of solute and surface tension depression contribution, the strongest surfactants coincide with the largest molar mass; this implies that loss of hygroscopicity from increases in molar volume may be compensated by shifts in surface tension depression. The surface tension depression (with respect to pure water) inferred for the samples considered here are similar to those from other SOA systems (Engelhart et al., 2008; Asa-Awuku et al., 2009; King et al., 2007), urban and regional aerosol (Padró et al., 2010), and biomass burning aerosol (Asa-Awuku et al., 2008).

Based on the observations presented here, a simple parameterization for the "apparent" $\kappa$ (i.e., that derived assuming a surface tension of water) for the organic fraction, $\kappa_{o}$, is $\kappa_{o} \sim 0.3 \varepsilon_{o}$, where $\varepsilon_{o}$ is the volume fraction of the watersoluble organics in the aerosol. When applying this parameterization to complex aerosol, special attention should be given to the nonlinear dependence of surface tension depression with organic fraction. Nevertheless, the invariance of the apparent hygroscopicity parameter for the WSOC across many studies suggests that this simple parameterization may be quite general in nature. This exciting prospect requires support from a broader $\mathrm{CCN}$ activity dataset of $\mathrm{CCN}$ activity, and will be the focus of future studies.

Acknowledgements. The work in this study was supported by a NSF CAREER Award and a NASA Earth and Space Science Fellowship. Additional funding for the ozonolysis experiments and speciation was provided by the US Department of Energy Biological and Environmental Research Program DE-FG02-05ER63983, Electric Power Research Institute, and US Environmental Protection Agency RD-83107501-0. We would like to thank Rodney Weber and Chris Hennigan of the Georgia Institute of Technology for the use of their Total Organic Carbon (TOC) Turbo Siever analyzer and Dionex DX-500 ion chromatograph.

Edited by: N. Pirrone 


\section{References}

Alfarra, M. R., Paulsen, D., Gysel, M., Garforth, A. A., Dommen, J., Prevot, A. S. H., Worsnop, D. R., Baltensperger, U., and Coe, H.: A mass spectrometric study of secondary organic aerosols formed from the photooxidation of anthropogenic and biogenic precursors in a reaction chamber, Atmos. Chem. Phys., 6, 52795293, 2006, http://www.atmos-chem-phys.net/6/5279/2006/.

Andreae, M. O. and Crutzen, P. J.: Atmospheric aerosols: Biogeochemical sources and role in atmospheric chemistry, Science, 276, 1052-1058, 1997.

Asa-Awuku, A., Nenes, A., Sullivan, A., Hennigan, C. J., and Weber, R. J.: Investigation of molar volume and surfactant characteristics of water-soluble organic compounds in biomass burning aerosol, Atmos. Chem. Phys., 8, 799-812, 2008, http://www.atmos-chem-phys.net/8/799/2008/.

Asa-Awuku, A., Engelhart, G. J., Lee, B. H., Pandis, S. N., and Nenes, A.: Relating CCN activity, volatility, and droplet growth kinetics of $\beta$-caryophyllene secondary organic aerosol, Atmos. Chem. Phys., 9, 795-812, 2009

Aschmann, S. M., Atkinson, R., and Arey, J.: Products of reaction of $\mathrm{OH}$ radicals with alpha-pinene, J. Geophys. Res.-A., 107, 4191, doi:10.1029/2001JD001098, 2002.

Baltensperger, U., Kalberer, M., Dommen, J., Paulsen, D., Alfarra, M. R., Coe, H., Fisseha, R., Gascho, A., Gysel, M., Nyeki, S., Sax, M., Steinbacher, M., Prevot, A. S. H., Sjoren, S., Weingartner, E., and Zenobi, R.: Secondary organic aerosols from anthropogenic and biogenic precursors, Faraday Discussions, 130, 265-278, 2005.

Brooks, S. D., DeMott, P. J., and Kreidenweis, S. M.: Water uptake by particles containing humic materials and mixtures of humic materials with ammonium sulfate, Atmos. Environ., 38(13), 1859-1868, 2004.

Bougiatioti, A., Fountoukis, C., Kalivitis, N., Pandis, S. N., Nenes, A. and Mihalopoulos, N.: Cloud condensation nuclei measurements in the eastern Mediterranean marine boundary layer: $\mathrm{CCN}$ closure and droplet growth kinetics, Atmos. Chem. Phys., 9, 7053-7066, 2009,

http://www.atmos-chem-phys.net/9/7053/2009/.

Cachier, H., Liousse, C., Buatmenard, P., and Gaudichet, A.: Particulate Content Of Savanna Fire Emissions, J. Atmos. Chem.., 22, 123-148, 1995.

Carrico, C. M., Petters, M. D., Kreidenweis, S. M., Collett, J. L., Engling, G., and Malm, W. C.: Aerosol hygroscopicity and cloud droplet activation of extracts of filters from biomass burning experiments, J. Geophys. Res.-Atmos., 113, D08206, doi:10.1029/2007JD009274, 2008.

Claeys, M., Wang, W., Ion, A. C., Kourtchev, I., Gelencser, A., and Maenhaut, W.: Formation of secondary organic aerosols from isoprene and its gas-phase oxidation products through reaction with hydrogen peroxide, Atmos. Environ., 38, 4093-4098, 2004.

Decesari, S., Facchini, M. C., Mircea, M., Cavalli, F., and Fuzzi, S.: Solubility properties of surfactants in atmospheric aerosol and cloud/fog water samples, J. Geophys. Res.-A., 108, 4685, doi:10.1029/2003JD003566, 2003.

Dinar, E., Taraniuk, I., Graber, E. R., Anttila, T., Mentel, T. F., and Rudich, Y.: Hygroscopic growth of atmospheric and model humic-like substances, J. Geophys. Res.-A., 112, D05211, doi:10.1029/2006JD007442, 2007.

Dinar, E., Taraniuk, I., Graber, E. R., Katsman, S., Moise, T.,
Anttila, T., Mentel, T. F., and Rudich, Y.: Cloud Condensation Nuclei properties of model and atmospheric HULIS, Atmos. Chem. Phys., 6, 2465-2481, 2006, http://www.atmos-chem-phys.net/6/2465/2006/.

Dommen, J., Metzger, A., Duplissy, J., Kalberer, M., Alfarra, M. R., Gascho, A., Weingartner, E., Prevot, A. S. H., Verheggen, B., and Baltensperger, U.: Laboratory observation of oligomers in the aerosol from isoprene/ $\mathrm{NO}_{\mathrm{x}}$ photooxidation, Geophys. Res. Lett., 33, L13805, doi:10.1029/2006GL026523, 2006.

Engelhart, G. J., Asa-Awuku, A., Nenes, A., and Pandis, S. N.: $\mathrm{CCN}$ activity and droplet growth kinetics of fresh and aged monoterpene secondary organic aerosol, Atmos. Chem. Phys., 8, 3937-3949, 2008

Fitzgerald, J. W., Hoppel, W. A., and Gelbard, F.: A onedimensional sectional model to simulate multicomponent aerosol dynamics in the marine boundary layer -1 . Model description, J. Geophys. Res.-A., 103, 16085-16102, 1998.

Forstner, H. J. L., Flagan, R. C., and Seinfeld, J. H.: Secondary organic aerosol from the photooxidation of aromatic hydrocarbons: Molecular composition, Environ. Sci. Technol., 31, 1345-1358, 1997.

Gao, S., Keywood, M., Ng, N. L., Surratt, J., Varutbangkul, V., Bahreini, R., Flagan, R. C., and Seinfeld, J. H.: Low-molecularweight and oligomeric components in secondary organic aerosol from the ozonolysis of cycloalkenes and alpha-pinene, J. Phys. Chem. A, 108, 10147-10164, 2004a.

Gao, S., Ng, N. L., Keywood, M., Varutbangkul, V., Bahreini, R., Nenes, A., He, J. W., Yoo, K. Y., Beauchamp, J. L., Hodyss, R. P., Flagan, R. C., and Seinfeld, J. H.: Particle phase acidity and oligomer formation in secondary organic aerosol, Environ. Sci. Technol., 38, 6582-6589, 2004b.

Graber, E. R. and Rudich, Y.: Atmospheric HULIS: How humiclike are they? A comprehensive and critical review, Atmos. Chem. Phys., 6, 729-753, 2006,

http://www.atmos-chem-phys.net/6/729/2006/.

Guenther, A., Hewitt, C. N., Erickson, D., Fall, R., Geron, C., Graedel, T., Harley, P., Klinger, L., Lerdau, M., McKay, W. A., Pierce, T., Scholes, B., Steinbrecher, R., Tallamraju, R., Taylor, J., and Zimmerman, P.: A Global-Model of Natural Volatile Organic-Compound Emissions, J. Geophys. Res.-A., 100, 88738892, 1995.

Gysel, M., Weingartner, E., Nyeki, S., Paulsen, D., Baltensperger, U., Galambos, I. and Kiss, G.: Hygroscopic properties of water-soluble matter and humic-like organics in atmospheric fine aerosol, Atmos. Chem. Phys., 4, 35-50, 2004

Hamilton, J. F., Lewis, A. C., Reynolds, J. C., Carpenter, L. J., and Lubben, A.: Investigating the composition of organic aerosol resulting from cyclohexene ozonolysis: low molecular weight and heterogeneous reaction products, Atmos. Chem. Phys., 6, 49734984, 2006, http://www.atmos-chem-phys.net/6/4973/2006/.

Henning, S., Rosenorn, T., D’Anna, B., Gola, A. A., Svenningsson, B., and Bilde, M.: Cloud droplet activation and surface tension of mixtures of slightly soluble organics and inorganic salt, Atmos. Chem. Phys., 5, 575-582, 2005, http://www.atmos-chem-phys.net/5/575/2005/.

Huff-Hartz, K. E., Rosenorn, T., Ferchak, S. R., Raymond, T. M., Bilde, M., Donahue, N. M., and Pandis, S. N.: Cloud condensation nuclei activation of monoterpene and sesquiterpene secondary organic aerosol, J. Geophys. Res.-A., 110, D14208, 
doi:10.1029/2004JD005754, 2005.

Jurányi, Z., Gysel, M., Duplissy, J., Weingartner, E., Tritscher, T., Dommen, J., Henning, S., Ziese, M., Kiselev, A., Stratmann, F., George, I. and Baltensperger, U.: Influence of gas-to-particle partitioning on the hygroscopic and droplet activation behaviour of $\alpha$-pinene secondary organic aerosol, Phys. Chem. Chem. Phys., 11, 8091-8097, doi:10.1039/b904162a, 2009.

Kalberer, M., Paulsen, D., Sax, M., Steinbacher, M., Dommen, J., Prevot, A. S. H., Fisseha, R., Weingartner, E., Frankevich, V., Zenobi, R., and Baltensperger, U.: Identification of polymers as major components of atmospheric organic aerosols, Science, 303, 1659-1662, 2004.

Kalberer, M., Sax, M., and Samburova, V.: Molecular size evolution of oligomers in organic aerosols collected in urban atmospheres and generated in a smog chamber, Environ. Sci. Technol., 40, 5917-5922, 2006.

Kanakidou, M., Seinfeld, J. H., Pandis, S. N., Barnes, I., Dentener, F. J., Facchini, M. C., Van Dingenen, R., Ervens, B., Nenes, A., Nielsen, C. J., Swietlicki, E., Putaud, J. P., Balkanski, Y., Fuzzi, S., Horth, J., Moortgat, G. K., Winterhalter, R., Myhre, C. E. L., Tsigaridis, K., Vignati, E., Stephanou, E. G., and Wilson, J.: Organic aerosol and global climate modelling: a review, Atmos. Chem. Phys., 5, 1053-1123, 2005,

http://www.atmos-chem-phys.net/5/1053/2005/.

Keywood, M. D., Varutbangkul, V., Bahreini, R., Flagan, R. C., and Seinfeld, J. H.: Secondary organic aerosol formation from the ozonolysis of cycloalkenes and related compounds, Environ.. Sci. Technol., 38, 4157-4164, 2004.

King, S. M., Rosenoern, T., Shilling, J. E., Chen, Q., and Martin, S. T.: Increased cloud activation potential of secondary organic aerosol for atmospheric mass loadings, Atmos. Chem. Phys., 9, 2959-2971, 2009, http://www.atmos-chemphys.net/9/2959/2009/.

King, S. M., Rosenoern, T., Shilling, J. E., Chen, Q., and Martin, S. T.: Cloud condensation nucleus activity of secondary organic aerosol particles mixed with sulfate, Geophys. Res. Lett., 34(24), L24806, doi:10.1029/2007GL030390, 2007.

Kiss, G., Tombacz, E., and Hansson, H. C.: Surface tension effects of humic-like substances in the aqueous extract of tropospheric fine aerosol, J. Atmos. Chem., 50, 279-294, 2005.

Köhler, H.: The nucleus in and the growth of hygroscopic droplets, Transactions of the Faraday Society, 43, 1152-1161, 1936.

Kroll, J. H., Ng, N. L., Murphy, S. M., Flagan, R. C., and Seinfeld, J. H.: Secondary organic aerosol formation from isoprene photooxidation, Environ. Sci. Technol., 40, 1869-1877, 2006.

Lance, S., Medina, J., Smith, J. N., and Nenes, A.: Mapping the operation of the DMT Continuous Flow CCN counter, Aerosol Sci. Tech., 40, 242-254, 2006.

Lance, S., Nenes, A., Mazzoleni, C., Dubey, M., Gates, H., Varutbangkul, V., Rissman, T. A., Murphy, S. M., Sorooshian, A., Brechtel, F., Flagan, R. C., Seinfeld, J. H., Feingold, G., and Jonsson, H.: CCN Activity, Closure and Droplet Growth Kinetics of Houston Aerosol During the Gulf of Mexico Atmospheric Composition and Climate Study (GoMACCS), J. Geoph. Res., 114, D00F15, doi:10.1029/2008JD011699, 2009

Langmuir, I.: The constitution and fundamental properties of solids and liquids. II. Liquids, J. Am. Chem. Soc., 39, 1848-1906, 1917.

Li, Z. D., Williams, A. L., and Rood, M. J.: Influence of soluble sur- factant properties on the activation of aerosol particles containing inorganic solute, J. Atmos. Sci., 55, 1859-1866, 1998.

Limbeck, A., Kulmala, M., and Puxbaum, H.: Secondary organic aerosol formation in the atmosphere via heterogeneous reaction of gaseous isoprene on acidic particles, Geophys. Res. Lett., 30, 1996, doi:10.1029/2003GL017738, 2003.

Moore, R. H., Ingall, E. D., Sorooshian, A., and Nenes, A.: Molar mass, surface tension, and droplet growth kinetics of marine organics from measurements of CCN activity, Geophys. Res. Lett., 35, L07801, doi:10.1029/2008GL033350, 2008.

Murphy, S. M., Agrawal, H., Sorooshian, A., Padró, L. T., Gates, H., Hersey, S., Welch, W. A., Jung, H., Miller, J. W., Cocker III, D. R., Nenes, A., Jonsson, H. H., Flagan, R. C., and Seinfeld, J. H.: Comprehensive simultaneous shipboard and airborne characterization of exhaust from a modern container ship at sea, Environ. Sci. Technol., 43(13), 4626-4640, doi:10.1021/es802413j, 2009.

Nenes, A., Moore, R. H, and Medina, J.: Scanning Mobility CCN Analysis - A method for fast measurements of size resolved CCN activity and growth kinetics, Aerosol Sci. Technol., in review, 2010.

Padró, L. T., Asa-Awuku, A., Morisson, R., and Nenes, A.: Inferring Thermodynamic Properties from CCN Activation Experiments: Single-component and Binary Aerosols, Atmos. Chem. Phys., 7, 5263-5274, 2007, http://www.atmos-chem-phys.net/7/5263/2007/.

Padró, L. T., Tkacik, D., Lathem, T., Hennigan, C. J., Sullivan, A. P., Weber, R. J., Huey, L. G., and Nenes, A., Investigation of CCN relevant properties and droplet growth kinetics of water-soluble aerosol fraction in Mexico City, J. Geophys. Res., in press, 2010.

Petters, M. D. and Kreidenweis, S. M.: A single parameter representation of hygroscopic growth and cloud condensation nucleus activity, Atmos. Chem. Phys., 7, 1961-1971, 2007, http://www.atmos-chem-phys.net/7/1961/2007/.

Petters, M. D., Wex, H., Carrico, C. M., Hallbauer, E., Massling, A., McMeeking, G. R., Poulain, L., Wu, Z., Kreidenweis, S. M., and Stratmann, F.: Towards closing the gap between hygroscopic growth and activation for secondary organic aerosol - Part 2: Theoretical approaches, Atmos. Chem. Phys., 9, 3999-4009, 2009, http://www.atmos-chem-phys.net/9/3999/2009/.

Petters, M. D., Kreidenweis, S. M., Prenni, A. J., Sullivan, R. C., Carrico, C. M., Koehler, K. A., and P. J. Ziemann, Role of molecular size in cloud droplet activation, Geoph. Res. Lett., 36, L22801, doi:10.1029/2009GL040131, 2009

Prenni, A. J., Petters, M. D., Kreidenweis, S. M., DeMott, P. J., and Ziemann, P. J.: Cloud droplet activation of secondary organic aerosol, J. Geophys. Res., 112, D10223, doi:10.1029/2006JD007963, 2007

Rissler, J., Vestin, A., Swietlicki, E., Fisch, G., Zhou, J., Artaxo, P., and Andreae, M. O.: Size distribution and hygroscopic properties of aerosol particles from dry-season biomass burning in Amazonia, Atmos. Chem. Phys., 6, 471-491, 2006, http://www.atmos-chem-phys.net/6/471/2006/.

Roberts, G. C. and Nenes, A.: A continuous-flow streamwise thermal-gradient $\mathrm{CCN}$ chamber for atmospheric measurements, Aerosol Sci. Tech., 39, 206-221, 2005.

Robinson, A. L., Donahue, N. M., Shrivastava, M. K., Weitkamp, E. A., Sage, A. M., Grieshop, A. P., Lane, T. E., Pierce, J. R., and Pandis, S. N.: Rethinking organic aerosols: Semivolatile emissions and photochemical aging, Science, 315, 1259-1262, 2007. 
Rogge, W. F., Mazurek, M. A., Hildemann, L. M., Cass, G. R., and Simoneit, B. R. T.: Quantification of Urban Organic Aerosols at a Molecular-Level - Identification, Abundance and SeasonalVariation, Atmos. Environ., 27, 1309-1330, 1993.

Salma, I., Ocskay, R., Varga, I., and Maenhaut, W.: Surface tension of atmospheric humic-like substances in connection with relaxation, dilution, and solution pH, J. Geophys. Res.-A., 111, D23205, doi:10.1029/2005JD007015, 2006.

Saxena, P. and Hildemann, L. M.: Water-soluble organics in atmospheric particles: A critical review of the literature and application of thermodynamics to identify candidate compounds, J. Atmos. Chem., 24, 57-109, 1996.

Seinfeld, J. H. and Pandis, S. N.: Atmospheric Chemistry \& Physics: From Air Pollution to Climate Change, John Wiley \& Sons, 761-823, 1998.

Shilling, J. E., King, S. M., Mochida, M., and Martin, S. T.: Mass spectral evidence that small changes in composition caused by oxidative aging processes alter aerosol CCN properties, J. Phys. Chem. A, 111, 3358-3368, 2007.

Shulman, M. L., Jacobson, M. C., Carlson, R. J., Synovec, R. E., and Young, T. E.: Dissolution behavior and surface tension effects of organic compounds in nucleating cloud droplets, Geophys. Res. Lett., 23, 277-280, 1996.

Snider, J. R. and Brenguier, J. L.: Cloud condensation nuclei and cloud droplet measurements during ACE-2, Tellus B, 52, 828$842,2000$.

Sorjamaa, R. and Laaksonen, A.: The influence of surfactant properties on critical supersaturations of cloud condensation nuclei, J. Aerosol Sci., 37, 1730-1736, 2006.

Sorjamaa, R., Svenningsson, B., Raatikainen, T., Henning, S., Bilde, M., and Laaksonen, A.: The role of surfactants in Kohler theory reconsidered, Atmos. Chem. Phys., 4, 2107-2117, 2004, http://www.atmos-chem-phys.net/4/2107/2004/.
Sullivan, A. P. and Weber, R. J.: Chemical characterization of the ambient organic aerosol soluble in water: 1. Isolation of hydrophobic and hydrophilic fractions with a XAD-8 resin, J. Geophys. Res.-A., 111, D05314, doi:10.1029/2005JD006485, 2006.

Tabazadeh, A.: Organic aggregate formation in aerosols and its impact on the physicochemical properties of atmospheric particles, Atmos. Env., 39, 5472-5480, 2005.

Turpin, B. J. and Lim, H. J.: Species contributions to PM2.5 mass concentrations: Revisiting common assumptions for estimating organic mass, Aerosol Sci. Technol., 35, 602-610, 2001.

Varutbangkul, V., Brechtel, F. J., Bahreini, R., Ng, N. L., Keywood, M. D., Kroll, J. H., Flagan, R. C., Seinfeld, J. H., Lee, A., and Goldstein, A. H.: Hygroscopicity of secondary organic aerosols formed by oxidation of cycloalkenes, monoterpenes, sesquiterpenes, and related compounds, Atmos. Chem. Phys., 6, 23672388, 2006, http://www.atmos-chem-phys.net/6/2367/2006/.

Wex, H., Hennig, T., Salma, I., Ocskay, R., Kiselev, A., Henning, S., Massling, A., Wiedensohler, A., and Stratmann, F.: Hygroscopic growth and measured and modeled critical super-saturations of an atmospheric HULIS sample, Geophys. Res. Lett., 34, 34, L02818, doi:10.1029/2006GL028260, 2007.

Wex, H., Petters, M. D., Carrico, C. M., Hallbauer, E., Massling, A., McMeeking, G. R., Poulain, L., Wu, Z., Kreidenweis, S. M., and Stratmann, F.: Towards closing the gap between hygroscopic growth and activation for secondary organic aerosol: Part 1 Evidence from measurements, Atmos. Chem. Phys., 9, 39873997, 2009, http://www.atmos-chem-phys.net/9/3987/2009/.

Yamasoe, M. A., Artaxo, P., Miguel, A. H., and Allen, A. G.: Chemical composition of aerosol particles from direct emissions of vegetation fires in the Amazon Basin: water-soluble species and trace elements, Atmos. Environ., 34, 1641-1653, 2000. 